\title{
PELAKSANAAN HYGENE DAN SANITASI PADA DEPOT AIR MINUM ISI ULANG
}

\author{
Muhammad Syahril ${ }^{1}$, Mappeatty Nyorong ${ }^{2}$, Nur Aini ${ }^{3}$ \\ 1,2,3 IImu Kesehatan Masyarakat, Institut Kesehatan Helvetia \\ Email : m.syahril0909@gmail.com
}

\begin{abstract}
ABSTRAK
Depot air minum isi ulang merupakan salah satu kegiatan usaha yang mengarah kepada air bersih untuk memenuhi kebutuhan air minum masyarakat dan juga memenuhi gaya hidup masyarakat sekarang yang mengutamakan kepraktisan dan kemudahan dalam memenuhi kebutuhan hidup. Adapun tujuan dalam penelitian ini adalah untuk mengetahui aspek pelaksanaan depot isi ulang di Desa Sapta Marga Kecamatan Manyak Payed Kabupaten Aceh Tamiang sesuai dengan hygiene serta sanitasi. Jenis penelitian ini merupakan survei analitik dengan rancangan cross sectional study. Penelitian dilakukan di Desa Sapta Marga Kecamatan Manyak Payed Kabupaten Aceh Tamiang dengan menggunakan teknik total sampling yaitu sebanyak 62 seluruh pemilik depot air minum sebanyak 31 orang dan pekerja (penjamah) depot air minum. Untuk menganalisis data tersebut digunakan uji regresi logistik.

Berdasarkan hasil penelitian diketahui bahwa hygiene dan sanitasi Air minum isi ulang di Desa Sapta Marga Kecamatan Manyak Payed Kabupaten Aceh Tamiang berhubungan dengan penjamah $(p=0,233)$, air baku $(p=0,012)$, sedangkan standar lokasi dan alat tidak berhubungan dengan hygiene dan sanitasi Air minum isi ulang di Desa Sapta Marga Kecamatan Manyak Payed Kabupaten Aceh Tamiang. Berdasarkan hasil penelitian, dapat disimpulkan penjamah, air baku, berhubungan dengan hygiene dan sanitasi Air minum isi ulang di Desa Sapta Marga Kecamatan Manyak Payed Kabupaten Aceh Tamiang. Sehingga adapun saran dalam penelitian ini diharapkan agar menjadi informasi bagi masyarakat mengenai hygiene dan sanitasi pada depot air minum isi ulang di Desa Sapta Marga Kecamatan Manyak Payed Kabupaten Aceh Tamiang agar lebih bijak dalam memilih depot air minum.
\end{abstract}

\section{Kata Kunci : Hygiene dan Sanitasi, Penjamah, Alat, Air Baku dan Standar Lokasi}

\begin{abstract}
Refill drinking water depots are one of the business activities that lead to clean water to meet the drinking water needs of the community and also meet people's current lifestyles which prioritizes practicality and convenience in meeting the needs of life. The purpose of this study was to determine aspects of the implementation of the refill depot in Sapta Marga Village, Manyak Payed District, Aceh Tamiang Regency in accordance with hygiene and sanitation. This type of research is an analytic survey with a cross sectional study design. The study was conducted in Sapta Marga Village, Manyak Payed Subdistrict, Aceh Tamiang District by using a total sampling technique of 62 all 31 drinking water depot owners and 31 workers of drinking water depots. To analyze the data logistic regression test was used. Based on the results of the study note that hygiene and sanitation Refill drinking water in Sapta Marga Village, Manyak Payed Subdistrict, Aceh Tamiang District is associated with handlers $(p=0.233)$, raw water $(p=0.012)$, while location standards and equipment are not related to hygiene and sanitation. Refill drinking water in Sapta Marga Village, Manyak Payed District, Aceh Tamiang Regency. Based on the results of the study, it can be concluded that handlers, raw water, are associated with hygiene and sanitation Refill drinking water in Sapta Marga Village, Manyak Payed District, Aceh Tamiang Regency. So that the suggestions in this study are expected to be information for the public about hygiene and sanitation in refill drinking water depots in Sapta Marga Village, Manyak Payed District, Aceh Tamiang Regency to be wiser in choosing drinking water depots.
\end{abstract}

\section{Keywords: Hygiene and Sanitation, Touchers, Equipment, Raw Water and Location Standards}

\section{PENDAHULUAN}

Air merupakan zat yang paling penting dalam kehidupan. Sekitar tiga per empat bagian dari tubuh manusia terdiri dari air dan tidak seorangpun dapat bertahan hidup lebih dari 4-5 hari tanpa minum air. Selain itu, air juga dipergunakan untuk memasak, mencuci, 
mandi, dan membersihkan kotoran yang ada di sekitar rumah.

Berdasarkan data WHO tahun 2019 diketahui bahwa hampir 40 persen penyakit mematikan di seluruh negara berkaitan dengan buruknya kualitas air, selain itu WHO juga mencatat bahwa ada sekitar 2,6 juta orang diseluruh dunia meninggal setiap tahunnya akibat penyakit yang disebabkan oleh air kotor atau air yang tidak memenuhi syarat kesehatan ${ }^{2}$

Berdasarkan data Kemenkes RI tahun 2019, sebanyak 33,4 juta penduduk di Indonesia masih mengalami kekurangan air bersih dan 99,7 juta jiwa kekurangan akses untuk ke fasilitas sanitasi yang baik. Capaian akses air bersih yang layak saat ini di Indonesia hanya mencapai 72,55 persen. Angka ini masih di bawah target Sustainable Development Goals (SDGs) yakni sebesar 100 persen. $^{3}$

Depot air minum isi ulang merupakan salah satu kegiatan usaha yang mengarah kepada air bersih untuk memenuhi kebutuhan air minum masyarakat dan juga memenuhi gaya hidup masyarakat sekarang yang mengutamakan kepraktisan dan kemudahan dalam memenuhi kebutuhan hidup. Masyarakat yang dulu terbiasa hidup dengan menggunakan tenaga sendiri sekarang terbiasa hidup dengan teknologi dan serba praktis. Jika dulu masyarakat terbiasa minum dengan air yang dimasak sendiri, sekarang masyarakat lebih cenderung mengkonsumsi air minum yang tidak perlu dimasak dan dapat diminum langsung ${ }^{4}$

Berdasarkan hasil pengujian kualitas 120 sampel air minum isi ulang di 10 kota besar (Jakarta, Bogor, Tangerang, Bekasi, Cikampek, Semarang, Yogyakarta, Surabaya, Medan, dan Denpasar) yang dilakukan di Laboratorium Teknologi dan Manajemen Lingkungan, Departemen Teknologi Industri Pertanian, Institut Pertanian Bogor (IPB) Tahun 2010, menunjukkan bahwa kualitas air minum yang diproduksi oleh depot air minum isi ulang bervariasi dari satu depot ke depot lainnya. Hal itu mengindikasikan bahwa ada perbedaan dalam karakteristik air baku, teknologi produksi, dan atau proses operasi dan pemeliharaan yang diterapkan di depot isi ulang air minum tersebut. Hasil studi tersebut sempat menjadi perhatian publik karena pada beberapa sampel ditemukan adanya kontaminasi mikroorganisme. Sekitar 16\% dari sampel tersebut terkontaminasi bakteri coliform, yang mengindikasikan buruknya kualitas sanitasi depot air minum isi ulang ${ }^{5}$

Peraturan Menteri Kesehatan Republik Indonesia Nomor 43 Tahun 2014 tentang
Higiene Sanitasi Depot Air bahwa dalam hal pengadaan sumber air usaha depot air minum isi ulang, air yang akan digunakan haruslah sesuai dengan syarat kualitas air minum yang baik. Air yang diperuntukkan bagi konsumsi manusia harus berasal dari sumber yang bersih dan aman. Batasan-batasan sumber air yang bersih dan aman tersebut, antara lain : 1) bebas dari kontaminasi kuman atau bibit penyakit. 2) Bebas dari substansi kimia yang berbahaya dan beracun. 3) Tidak berasa dan tidak berbau. 4) Dapat dipergunakan untuk mencukupi kebutuhan domestik dan rumah tangga. 5) Memenuhi standar minimal yang ditentukan oleh WHO antara lain dari aspek persyaratan fisik, kimia dan mikrobiologis. Persyaratan fisik air bersih antara lain jernih atau tidak keruh, tidak berwarna, tidak berbau, tidak mengandung padatan, temperatur normal $\left(29^{\circ} \mathrm{C}\right)$. Persyaratan kimia air bersih antara lain, $\mathrm{pH}$ netral $(6,8-9,0)$, tidak mengandung kimia beracun, tidak mengandung garam atau ion-ion logam berbahaya, kesadahan rendah, dan tidak mengandung bahan organik. Sedangkan persyaratan mikrobiologis antara lain tidak mengandung bakteri pathogen yang dapat menyebarkan penyakit ${ }^{6}$

(f) Dinding kedap air, permukaan rata, halus, tidak licin, tidak retak,tidak menyerap debu, dan mudah dibersihkan, serta warna yang terang dan cerah; atap dan langit-langit harus kuat, anti tikus, mudah dibersihkan, tidak menyerap debu, permukaan rata, dan berwarna terang, serta mempunyai ketinggian yang memungkinkan adanya pertukaran udara yang cukup atau lebih tinggi dari ukuran tandon air; (g) memiliki pintu dari bahan yang kuat dan tahan lama, berwarna terang, mudah dibersihkan, dan berfungsi dengan baik; $(h)$ pencahayaan cukup terang untuk bekerja, tidak menyilaukan dan tersebar secara merata; (1) ventilasi harus dapat memberikan ruang pertukaran/peredaran udara dengan baik; (j) kelembaban udara dapat mendukung kenyamanan dalam melakukan pekerjaan/aktivitas; (k) memiliki akses fasilitas sanitasi dasar, seperti jamban, saluran pembuangan air limbah yang alirannya lancar dan tertutup, tempat sampah yang tertutup serta tempat cuci tangan yang dilengkapi air mengalir dan sabun; dan (I) bebas dari vektor dan binatang pembawa penyakit seperti lalat, tikus dan kecoa ${ }^{7}$

Desa Sapta Marga Kecamatan Manyak Payed Kabupaten Aceh Tamiang merupakan salah satu daerah yang memiliki jumlah depot air minum yang cukup tinggi. Berdasarkan data Dinas Kesehatan Kabupaten Aceh Tamiang, 
jumlah depot air minum yang terdapat di Desa Sapta Marga Kecamatan Manyak Payed Kabupaten Aceh Tamiang adalah 31 depot air minum. Selain itu jumlah penjualan air minum isi ulang pada depot air minum di Desa Sapta Marga Kecamatan Manyak Payed Kabupaten Aceh Tamiang juga tinggi. Setiap harinya depot air minum menjual sekitar 80 sampai 100 galon kepada konsumen.

Berdasarkan survey awal yang dilakukan di Desa Sapta Marga Kecamatan Manyak Payed Kabupaten Aceh Tamiang, diketahui bahwa dari 31 depot air minum isi ulang yang ada di Desa Sapta Marga Kecamatan Manyak Payed Kabupaten Aceh Tamiang, ada 21 depot air minum yang tidak sesuai dengan Peraturan Menteri Kesehatan Republik Indonesia Nomor 43 Tahun 2014, yaitu depot air minum tidak memperhatikan standar lokasi, misalnya konstruksi lantai, dinding dan plafon area produksi berdebu dan jarang dibersihkan, dinding ruang pengisian berwarna tidak terang, karyawan yang sedang bekerja di depot sering meludah sembarang, merokok, dan tidak mencuci tangan sebelum melakukan pekerjaan. Kadang-kadang, wadah yang dibawa konsumen tidak di cuci bersih dengan cara yang benar, selang dan pompa yang dipakai untuk bongkar muat air baku tidak diberi penutup yang baik, sehingga kemungkinan memiliki kontaminasi.

Depot air isi ulang dikembangkan di Aceh Tamiang didirikan sejak tahun 2000 dan hingga tahun 2016 tidak ada keluhan, akan tetapi sejak tahun 2019 ada banyak keluhan dari masyarakat yang berhubungan dengan water borne diseases. Oleh sebab itu, peneliti tertarik untuk melakukan penelitian tentang "Pelaksanaan Hygiene dan Sanitasi pada Depot Air Minum Isi Ulang di Desa Sapta Marga Kecamatan Manyak Payed Kabupaten Aceh Tamiang".

\section{BAHAN DAN METODE}

Penelitian ini menggunakan jenis penelitian kuantitaif dengan rancangan cross sectional study. Lokasi penelitian ini dilakukan di Desa Sapta Marga Kecamatan Manyak Payed Kabupaten Aceh Tamiang. Waktu Penelitian berlangsung mulai bulan Oktober sampai dengan November 2019

Populasi penelitian kuantitatif yaitu seluruh pemiliki depot dan penjamah di Desa Sapta Marga Kecamatan Manyak Payed Kabupaten Aceh sebanyak 62. Teknik yang digunakan adalah total sampling berjumlah 62 orang. Data hasil survey dianlaisis dengan menggunakan uji Chi Square dan regresi logistik.

\section{HASIL}

\section{Analisis Data Univariat}

Berdasarkan data yang diperoleh dari hasil penelitian dengan 62 responden dapat dilihat dalam tabel distribusi frekuensi sebagai berikut.

Tabel 1

Distribusi Karakteristik Responden Berdasarkan Umur, Pendidikan

\begin{tabular}{lcc}
\hline Umur & F & $\%$ \\
\hline 26-35 Tahun & 4 & 6,45 \\
36-45 Tahun & 21 & 33,87 \\
46-55 Tahun & 27 & 35,55 \\
56-65 Tahun & 10 & 16,13 \\
\hline Pendidikan & $\mathbf{F}$ & $\%$ \\
\hline SD & 2 & 3,23 \\
SMP & 11 & 17,74 \\
SMA & 29 & 46,77 \\
PT & 20 & 32,26 \\
\hline Total & $\mathbf{6 2}$ & $\mathbf{1 0 0}$ \\
\hline
\end{tabular}

Berdasarkan tabel 1 di atas, diketahui bahwa dari 62 responden, sebagian besar responden berumur 46-55 tahun yaitu sebanyak $27 \quad(35,55 \%)$ responden. Berdasarkan pendidikan diketahui bahwa dari 62 responden, sebagian besar responden berpendidikan SMA yaitu sebanyak $29(46,77 \%)$ responden.

\section{Analisis Data Bivariat}

Untuk mengetahui analisis bivariat di Desa Sapta Marga Kecamatan Manyak Payed Kabupaten Aceh Tamiang, dapat dilihat pada tabel dibawah ini: 
Tabel 2

Bivariat Di Desa Sapta Marga Kecamatan Manyak Payed Kabupaten Aceh Tamiang

\begin{tabular}{|c|c|c|c|c|c|c|c|}
\hline \multirow{3}{*}{ Standar Lokasi } & \multicolumn{6}{|c|}{ Hygiene Dan Sanitasi } & \multirow{3}{*}{ P value } \\
\hline & \multicolumn{2}{|c|}{$\begin{array}{c}\text { Tidak } \\
\text { Memenuhi } \\
\text { Syarat } \\
\end{array}$} & \multicolumn{2}{|c|}{$\begin{array}{l}\text { Memenuhi } \\
\text { Syarat }\end{array}$} & \multicolumn{2}{|c|}{ Total } & \\
\hline & $\mathrm{n}$ & $\%$ & $\mathrm{n}$ & $\%$ & $\mathrm{n}$ & $\%$ & \\
\hline Tidak Memenuhi Syarat & 16 & 25,81 & 9 & 14,52 & 25 & 40,32 & 0,233 \\
\hline Memenuhi Syarat & 18 & 29,32 & 19 & 30,64 & 37 & 59,68 & \\
\hline \multicolumn{8}{|l|}{ Alat } \\
\hline Tidak Memenuhi Syarat & 14 & 22,58 & 9 & 14,52 & 23 & 37,10 & 0,464 \\
\hline Memenuhi Syarat & 20 & 32,26 & 19 & 30,64 & 39 & 62,90 & \\
\hline \multicolumn{8}{|l|}{ Penjamah } \\
\hline Tidak Memenuhi Syarat & 25 & 40,32 & 10 & 16,13 & 35 & 56,45 & \\
\hline Memenuhi Syarat & 9 & 14,52 & 18 & 29,03 & 27 & 43,55 & 0,003 \\
\hline \multicolumn{8}{|l|}{ Air Baku } \\
\hline Tidak Memenuhi Syarat & 30 & 48,39 & 2 & 3,23 & 32 & 51,61 & \\
\hline Memenuhi Syarat & 4 & 6,45 & 26 & 41,94 & 30 & 48,39 & 0,000 \\
\hline Total & 34 & 54,84 & 28 & 45,16 & 62 & 100 & \\
\hline
\end{tabular}

Berdasarkan tabel 2 diketahui bahwa dari 62 responden yang diteliti, sebagian besar responden memenuhi syarat standar lokasi air minum isi ulang yaitu sebanyak $37(59,68 \%)$ responden. Dari $37(59,68 \%)$ responden tersebut, ada sebanyak 18 (29,32\%) responden memenuhi syarat standar lokasi air minum isi ulang dan tidak memenuhi syarat hygiene dan sanitasi isi ulang air minum, dan sebanyak 19 (30,64\%) responden memenuhi syarat standar lokasi air minum isi ulang dan memenuhi syarat hygiene dan sanitasi isi ulang air minum. Berdasarkan hasil perhitungan uji statistik diperoleh nilai $p$ significancy yaitu $0,015>0,233$, sehingga dapat disimpulkan bahwa tidak ada hubungan standar lokasi dengan hygiene dan sanitasi Air minum isi ulang di Desa Sapta Marga Kecamatan Manyak Payed Kabupaten Aceh Tamiang

Dari 62 responden yang diteliti, sebagian besar responden memenuhi syarat alat air minum isi ulang yaitu sebanyak 39 (62,90\%) responden. Dari 39 (62,90\%) responden tersebut, ada sebanyak 20 $(32,26 \%)$ responden memenuhi syarat alat air minum isi ulang dan tidak memenuhi syarat hygiene dan sanitasi isi ulang air minum, dan sebanyak $19(30,64 \%)$ responden memenuhi syarat standar lokasi air minum isi ulang dan memenuhi syarat hygiene dan sanitasi isi ulang air minum. Berdasarkan hasil perhitungan uji statistik diperoleh nilai $p$ significancy yaitu $0,015>0,464$, sehingga dapat disimpulkan bahwa tidak ada hubungan alat dengan hygiene dan sanitasi Air minum isi ulang di Desa Sapta Marga Kecamatan Manyak Payed Kabupaten Aceh Tamiang.
Berdasarkan tabel 4.9 diketahui bahwa dari 62 responden yang diteliti, sebagian besar responden tidak memenuhi syarat standar penjamah air minum isi ulang yaitu sebanyak 35 (56,45\%) responden. Dari 35 (56,45\%) responden tersebut, ada sebanyak 25 $(40,32 \%)$ responden tidak memenuhi syarat penjamah air minum isi ulang dan tidak memenuhi syarat hygiene dan sanitasi isi ulang air minum, dan sebanyak 10 (16,13\%) responden tidak memenuhi syarat penjamah air minum isi ulang dan memenuhi syarat hygiene dan sanitasi isi ulang air minum. Berdasarkan hasil perhitungan uji statistik diperoleh nilai $p$ significancy yaitu $0,015<$ 0,003, sehingga dapat disimpulkan bahwa ada hubungan penjamah dengan hygiene dan sanitasi Air minum isi ulang di Desa Sapta Marga Kecamatan Manyak Payed Kabupaten Aceh Tamiang.

Dari 62 responden yang diteliti, sebagian besar responden tidak memenuhi syarat air baku air minum isi ulang yaitu sebanyak $32(51,61 \%)$ responden. Dari 32 $(51,61 \%)$ responden tersebut, ada sebanyak $30 \quad(48,39 \%)$ responden tidak memiliki memenuhi syarat air baku air minum isi ulang dan tidak memenuhi syarat hygiene dan sanitasi isi ulang air minum, dan sebanyak 2 $(3,23 \%)$ responden tidak memenuhi syarat air baku air minum isi ulang dan memenuhi syarat hygiene dan sanitasi isi ulang air minum. Berdasarkan hasil perhitungan uji statistik diperoleh nilai $p$ significancy yaitu $0,015<$ 0,000 , sehingga dapat disimpulkan bahwa ada hubungan air baku hygiene dan sanitasi Air minum isi ulang di Desa Sapta Marga 
Kecamatan Manyak Payed Kabupaten Aceh Tamiang.

\section{Analisis Multivariat}

Adapun variable yang paling dominan berhubungan dengan Hygiene dan sanitasi sanitasi Air minum isi ulang di Desa Sapta Marga Kecamatan Manyak Payed Kabupaten Aceh Tamiang

\begin{tabular}{|c|c|c|c|c|}
\hline \multicolumn{5}{|c|}{$\begin{array}{c}\text { Analisis Multivariat Variable yang Paling Dominan berhubungan dengan Hygiene dan Sanitasi } \\
\text { Sanitasi Air Minum Isi Ulang Di Desa Sapta Marga Kecamatan Manyak Payed } \\
\text { Kabupaten Aceh Tamiang }\end{array}$} \\
\hline Variabel & B & P vlue & $\operatorname{Exp}(B) O R$ & 95\%Cl for $\operatorname{Exp}(\mathrm{B})$ \\
\hline Penjamah & 19,986 & 0,047 & 0,315 & $0,451-12,914$ \\
\hline Air baku & 22,406 & 0,003 & 0,422 & $0,500-13,091$ \\
\hline
\end{tabular}

Berdasarkan tabel 3 diatas dapat dilihat bahwa analisis regresi logistik menghasilkan satu variabel yang paling dominan berhubungan dengan Pelaksanaan Hygiene dan Sanitasi pada air minum isi ulang Isi Ulang di Desa Sapta Marga Kecamatan Manyak Payed Kabupaten Aceh Tamiang dengan $p$ value $<0,05$, yaitu variabel air baku dengan signifikan 0,003 ( $\mathrm{p}$ value $<0,05), \mathrm{OR}=$ $0,422(95 \% \mathrm{Cl}=0,500-13,091)$ artinya responden yang tidak memenuhi syarat air baku mempunyai peluang 0,422 kali terhadap pelaksanaan hygiene dan sanitasi pada air minum isi ulang yang tidak memenuhi syarat, dibandingkan dengan responden yang tmemenuhi syarat air baku isi ulang di Desa Sapta Marga Kecamatan Manyak Payed Kabupaten Aceh Tamiang.

\section{PEMBAHASAN}

Hasil penelitian tentang hubungan standar lokasi dengan hygiene dan sanitasi air minum isi ulang Di Desa Sapta Marga Kecamatan Manyak Payed Kabupaten Aceh Tamiang menunjukkan bahwa dari 62 responden yang diteliti, sebagian besar responden memenuhi syarat standar lokasi air minum isi ulang yaitu sebanyak $37(59,68 \%)$ responden. Dari $37 \quad(59,68 \%)$ responden tersebut, ada sebanyak 18 (29,32\%) responden memenuhi syarat standar lokasi air minum isi ulang dan tidak memenuhi syarat hygiene dan sanitasi isi ulang air minum, dan sebanyak 19 (30,64\%) responden memenuhi syarat standar lokasi air minum isi ulang dan memenuhi syarat hygiene dan sanitasi isi ulang air minum. Berdasarkan hasil perhitungan uji statistik diperoleh nilai $p$ significancy yaitu $0,015>0,233$, sehingga dapat disimpulkan bahwa tidak ada hubungan standar lokasi dengan hygiene dan sanitasi Air minum isi ulang di Desa Sapta Marga Kecamatan Manyak Payed Kabupaten Aceh Tamiang.
Tidak adanya hubungan antara standar lokasi dengan hygiene dan sanitasi Air minum isi ulang di Desa Sapta Marga Kecamatan Manyak Payed Kabupaten Aceh Tamiang disebabkan karena sebagian besar lokasi telah memenuhi syarat Peraturan Menteri Kesehatan Republik Indonesia Nomor 43 Tahun 2014 tentang Depot Air Minum Isi Ulang, yaitu berada di daerah yang bebas dari pencemaran lingkungan dan penularan penyakit, memiliki bangunan kuat, aman, mudah dibersihkan, dan mudah pemeliharaannya, lantai kedap air, permukaan rata, halus, tidak licin, tidak retak, tidak menyerap debu, dan mudah dibersihkan, serta kemiringan cukup landai untuk memudahkan pembersihan dan tidak terjadi genangan air, dinding kedap air, permukaan rata, halus, tidak licin, tidak retak, tidak menyerap debu, dan mudah dibersihkan, serta warna yang terang dan cerah dan atap dan langit-langit harus kuat, anti tikus, mudah dibersihkan, tidak menyerap debu, permukaan rata, dan berwarna terang, serta mempunyai ketinggian yang memungkinkan adanya pertukaran udara yang cukup atau lebih tinggi dari ukuran tandon air, memiliki pintu dari bahan yang kuat dan tahan lama, berwarna terang, mudah dibersihkan, dan berfungsi dengan baik, memiliki akses fasilitas sanitasi dasar, seperti jamban, saluran pembuangan air limbah yang alirannya lancar dan tertutup, tempat sampah yang tertutup serta tempat cuci tangan yang dilengkapi air mengalir dan sabun.

Higiene dan sanitasi DAMIU air minum merupakan salah satu upaya dalam bidang kesehatan untuk mengurangi faktor-faktor yang menjadikan air minum tercemar dan proses pengolahan, penyimpanan dan pembagian air minum. Keputusan Menteri Perindustrian dan Perdagangan RI. No 
651/MPP/Kep/10/2004 tentang persyaratan teknis depo air minum dan perdagangannya dan pedoman pelaksanaan penyelenggaraan higiene sanitasi depo air minum. Kualitas air minum yang aman dikonsumsi diatur dalam Permenkes RI No. 492/Menkes/Per/IV/2010 tentang syarat-syarat kualitas air minum yang meliputi persyaratan fisik, kimiawi, bakteorologis dan radioakti

Akan tetapi ada juga depot air minum isi ulang yang belum memenuhi syarat dan berdampak pada hygiene dan sanitasi Air minum isi ulang di Desa Sapta Marga Kecamatan Manyak Payed Kabupaten Aceh Tamiang yaitu sebanyak 25 depot. Keberadaan depot tersebut sering sekali mendapat peringatan dari dinas kesehatan agar memerhatikan lokasi bangunan tempat usaha. Ketidak higyeneannya misalnya seperti bangunanannya susah dibersihkan, lantai dinding berlumut dan kurang pencahayaan.

Tidak adanya hubungan alat dengan hygiene dan sanitasi Air minum isi ulang di Desa Sapta Marga Kecamatan Manyak Payed Kabupaten Aceh Tamiang disebabkan oleh keperdulian pemiliki usaha terhadap hygiene dan sanitasi Air minum isi ulang dan merupakan salah satu syarat yang harus dipenuhi dalam membuka usaha depot air minum.

Berdasarkan hasil penelitian
menunjukkan bahwa peralatan dan
perlengkapan yang digunakan antara lain
pipa pengisian air baku, tandon air
baku, pompa penghisap dan penyedot, filter, mikrofilter, wadah/galon air baku atau Air Minum, kran pengisian Air Minum, kran pencucian/pembilasan wadah/galon, kran penghubung, dan peralatan desinfeksi harus terbuat dari bahan tara pangan (food grade) atau tidak menimbulkan racun, tidak menyerap bau dan rasa, tahan karat, tahan pencucian dan tahan disinfeksi ulang sebagaian besar telah memenuhi syarat. Mikrofilter dan desinfektor tidak kadaluarsa, tandon air baku harus tertutup dan terlindung; wadah/galon untuk air baku atau Air Minum sebelum dilakukan pengisian harus dibersihkan dengan cara dibilas terlebih dahulu dengan air produksi paling sedikit selama 10 (sepuluh) detik dan setelah pengisian diberi tutup yang bersih; dan wadah/galon yang telah diisi Air Minum harus langsung diberikan kepada konsumen dan tidak boleh disimpan pada DAM lebih dari 1x24 jam

Hasil penelitian tentang hubungan penjamah dengan hygiene dan sanitasi air minum isi ulang di Desa Sapta Marga Kecamatan Manyak Payed Kabupaten Aceh
Tamiang menujukkan bahwa dari 62 responden yang diteliti, sebagian besar responden tidak memenuhi syarat standar penjamah air minum isi ulang yaitu sebanyak $35(56,45 \%)$ responden. Dari 35 (56,45\%) responden tersebut, ada sebanyak 25 $(40,32 \%)$ responden tidak memenuhi syarat penjamah air minum isi ulang dan tidak memenuhi syarat hygiene dan sanitasi isi ulang air minum, dan sebanyak $10(16,13 \%)$ responden tidak memenuhi syarat penjamah air minum isi ulang dan memenuhi syarat hygiene dan sanitasi isi ulang air minum. Berdasarkan hasil perhitungan uji statistik diperoleh nilai $p$ significancy yaitu $0,015<$ 0,003 , sehingga dapat disimpulkan bahwa ada hubungan penjamah dengan hygiene dan sanitasi Air minum isi ulang di Desa Sapta Marga Kecamatan Manyak Payed Kabupaten Aceh Tamiang.

Penjamah merupakan orang yang melakukan pengolahan air minum pada DAM melalui operasional mesin dan berbagai peralatan. Karyawan pada DAM haruslah mengetahui cara prosedur pengolahan air yang dilakukan. Dalam pengolahan minuman, tidak sembarang orang yang bisa dijadikan karyawan. Karena air minum merupakan salah satu mediayang dapat menjadi penularan penyakit. Sehingga air minum hasil olahan harus benar-benar terjamin untuk dikonsumsi. Maka karyawan/pengolah air minum harus benar-benar dalam kondisi sehat dan bersih dalam melakukan pengolahan air.

Berbagai hal yang harusnya menjadi syarat mutlak dipenuhi oleh seorang karyawan, sesuai dengan aspek yang peneliti amati, diantaranya kondisi badan yang sehat secara fisik. Hal ini dapat mempengaruhi kinerja karyawan yang maksimal dengan fisik yang sehat dan kuat. Bebas dari luka, penyakit kulit, flu dan batuk, yang dapat mengakibatkan pencemaran terhadap air minum berupa penyebaran virus dan bakteri jika penderita tersebut masih dalam kondisi carier. Harus menggunakan pakaian bersih dan sepatu, jika pakaian tidak bersih bisa saja kotoran pada pakaian mencemari air olahan, mesin dan peralatan lainnya, disamping dapat mempengaruhi nilai estetika bagi para konsumen. Kemudian penggunaan sepatu, agar dapat memberikan kesehatan berupa pencegahan terhadap kutuair pada kaki dan keselamatan kerja bagi karyawan.

Karyawan juga harus berperilaku sehat dengan mencuci tangan pakai sabun menggunakan air mengalir agar tangan dapat bersih dari kotoran dan bakteri yang dapat mengkontaminasi air minum. Sebelum makan sajakita harus mencuci tangan pakai 
sabun,terlebih lagi dalam mengolah air minum yang sangat mudah terkontaminasi oleh tangan yang mengandung kotoran dan bakteri.Karyawan tidak boleh makan, meludah dan merokok saat melakukan pengisian air kedalam botol gallon. Saat makan dan meludah memungkinkan makanan dan droplet/percikan ludah mencemari air olahan. Adapun asap rokok dengan mudah dapat terkontaminasi dengan air yang mengalir dengan bau asap rokok yang tajam dan debu dari pembakaran rokok dengan mudah terbawa oleh angin. Seharusnya semua karyawan DAM memiliki higiene yang bersih dan perilaku yang sehat, agar menghasilkan olahan air minum yang bersih dan sehat pula bagi konsumen.

Pencemaran air minum dapat terjadi di tingkat produsen, penjual dan konsumen. Kurangnya pengetahuan dari penjual dan konsumen dalam hal kesehatan yaitu perlakuan terhadap air layak konsumsi misalnya penyimpanan air yang tidak memenuhi syarat, terkena sinar matahari secara langsung, tempat yang terlalu lembab dapat memicu pertumbuhan bakteri. Kondisi higiene penjamah ini meliputi semua hal yang digunakan dan dilakukan oleh penjamah. Dimulai dari kebersihan seragam, penggunaan tutup kepala, penggunaan celemek, penggunaan penutup mulut hingga kuku yang bersih.

Selain itu juga dilihat perilaku penjamah seperti mencuci tangan, tidak meludah sembarangan, mengobrol, tidak makan dan minum, tidak merokok, dan tidak menggaruk selama kerja. Berbicara, makan, minum dan merokok pada saat bekerja berpotensi untuk terjadinya kontaminasi kuman yang berasal dari droplet penjamah.

Berdasarkan penelitian Wandrivel, diketahui bahwa mulut merupakan salah satu tempat bersarangnya bakteri, untuk itu sebaiknya menggunakan masker saat pengolahan agar tidak ada penyebaran bakteri dari mulut. Berdasarkan teori yang dikemukakan oleh Fathonah S bahwa kuku tangan sering menjadi sumber kontaminasi atau mengakibatkan kontaminasi silang.Sebagian besar penjamah tidak mencuci tangan dengan sabun sebelum melakukan pekerjaan sehingga dapat menimbulkan kontaminasi

Berdasarkan hasil survey peneliti terhadap penjamah di Desa Sapta Marga Kecamatan Manyak Payed Kabupaten Aceh Tamiang diketahui bahwa masih ada yang memiliki kuku yang panjang dan tidak bersih pada saat melakukan pekerjaan, hal ini dapat menyebabkan perpindahan bakteri dari tangan ke air minum. Banyak penjamah yang tidak memenuhi standar penjamah, seperti ada beberapa penjamah yang memiliki luka, penyakit kulit seperti panu, kudis dan kurap, tidak semua penjamah depot air minum menggunakan pakaian kerja, tutup kepala dan sepatu yang sesuai, tidak semua penjamah mencuci tangan sebelum melakukan pekerjaan, terutama pada saat penanganan wadah dan pengisian. Sebagian penjamah makan, merokok, meludah atau melakukan tindakan lain selama melakukan pekerjaan yang dapat menyebabkan pencemaran terhadap air minum.

Dengan demikian penjamah merupakan salah satu faktor yang dapat memengaruhi hygiene dan sanitasi Air minum isi ulang di Desa Sapta Marga Kecamatan Manyak Payed Kabupaten Aceh Tamiang. Penjamah yang tidak memperhatikan hygiene dan sanitasi dapat menyebarkan penyakit. di Desa Sapta Marga Kecamatan Manyak Payed Kabupaten Aceh Tamiang banyak penjamah yang mengalami sakit gatal-gatal pada tangan, selain itu banyak penjamah yang merokok pada saat proses pengisian air minum serta mengisi air minum sambil menggaruk-garuk bagian tubuh.

Seharusnya, pada saat sedang bekerja, seorang penjamah tidak boleh merokok pada saat bekerja, menggaruk dan harus mencuci tangan sebelum dan sesudah bekerja dan harus menggunakan pakaian kerja yang bersih dan rapi. Pakaian kerja yang bersih akan menjamin sanitasi dan higiene pengolahan makanan karena tidak terdapat debu atau kotoran yang melekat pada pakaian yang secara tidak langsung dapat menyebabkan pencemaran.

Berdasarkan hasil pemantauan peneliti di Desa Sapta Marga Kecamatan Manyak Payed Kabupaten Aceh Tamiang, diketahui bahwa Air baku yang digunakan untuk diolah menjadi air minum tidak memenuhi standar mutu yang ditetapkan dalam Peraturan Menteri Kesehatan. Air baku yang digunakan tersebut tidak jelas sumbernya dan untuk lebih amannya, maka sumber air baku tersebut harus pula diawasi. Dalam hal ini harus dilakukan pengawasan secara periodik dan berkelanjutan terhadap mutu air baku tersebut dengan pemeriksaan laboratorium baik dari aspek fisik,bakteriologis, maupun kimia. Sehingga air baku tersebut memenuhi standar mutu yang telah ditetapkan. tidak semua air minum adalah air baku yang telah diproses dan aman untuk diminum dan memenuhi persyaratan mutu sesuai Peraturan Menteri Kesehatan untuk diolah menjadi produk air minum. Ada beberapa depot yang tidak 
memperhatikan proses pengolahan terhadap air baku dengan beberapa tahapan proses sampai dengan menjadi air minum. Depot Air Minum harus melakukan pengawasan secara periodik terhadap mutu air baku, yang ditunjukkan dengan hasil uji laboratorium dari Pemasok.

Seharusnya pengujian mutu air baku dilakukan minimal satu kali dalam tiga bulan untuk analisa coliform, dua kali dalam satu tahun untuk analisa kimia dan fisika secara lengkap, pengujian mutu air baku harus dilakukan di laboratorium pemeriksaan kualitas air yang ditunjuk oleh pemerintah kabupaten/kota atau yang terakreditasi, namun tidak semua pengusahan depot melakukannya karena biaya yang dikeluarkan terbilang sangat banyak.

Sumber air baku merupakan salah satu faktor yang dapat mempengaruhi hasil olahan menjadi air minum yang terjamin. Karena 84tidak menutup kemungkinan air minum dengan kualitas yang tidak memenuhi syarat disebabkan oleh air baku yang tidak layak untuk diolah. Sehingga setiap air baku dari berbagai sumber yang ada, haruslah diperiksa terlebih dahulu melalui uji laboratorium. Air PDAM belum tentu layak secara langsung dijadikan air baku untuk diolah menjadi air minum pada DAM, melihat air tersebut merupakan air perpipaan. Hal ini bisa saja dalam perjalanan perpipaan air tersebut mengalami indikasi cemaran baik dari segi fisika, bakteriologis, maupun kimia. Selain air PDAM, air sumur bor juga belum tentu layak secara langsung dijadikan sebagai air baku untuk diolah menjadi air minum pada DAM. Melihat kualitas airsumur bordipengaruhi oleh berbagai macamfaktor diantaranya, kedalaman, lokasi, jenis tanah, jangkauan sumber pencemar, rembesan air limbah, serta jarak TPA.

\section{KESIMPULAN DAN SARAN}

Berdasarkan hasil penelitian, dapat disimpulkan penjamah, air baku, berhubungan dengan hygiene dan sanitasi Air minum isi ulang di Desa Sapta Marga Kecamatan Manyak Payed Kabupaten Aceh Tamiang.

Sehingga adapun saran dalam penelitian ini diharapkan agar menjadi informasi bagi masyarakat mengenai hygiene dan sanitasi pada depot air minum isi ulang di Desa Sapta Marga Kecamatan Manyak Payed Kabupaten Aceh Tamiang agar lebih bijak dalam memilih depot air minum.

\section{DAFTAR PUSTAKA}

1. Effendi, Hefni. Telaah kualitas air, bagi pengelolaan sumber daya dan lingkungan. Kanisius; 2013.

2. World Health Organization. Definition, diagnosis and classification of waterclean: report of a WHO consultation. Part 1,. No. WHO/NCD/NCS/99.2. Geneva: World health organization; 2019.

3. Kementerian Kesehatan Republik Indonesia. Direktorat Jenderal Pengendalian, dan Penyehatan Lingkungan. Pedoman nasional pengendalian penyakit. Jakarta: Kementerian Kesehatan Indonesia 6 ; 2017.

4. Asmadi, Khayan, Kasjono H.S. Pengolahan Air Minum. Gosyen Publishing. Yogyakarta; 2016.

5. Wandrivel, Rido, Netty Suharti, and Yuniar Lestari. Kualitas air minum yang diproduksi depot air minum isi ulang berdasarkan persyaratan mikrobiologi. Jurnal Kesehatan 1.3; 2012.

6. Departemen Kesehatan, R. I. Permenkes No. 492/Menkes/Per/IV/2010 Tentang Persyaratan Kualitas Air Minum. Jakarta: Departemen Kesehatan RI; 2010. 